\title{
Social Behavior of Early Childhood Through Playing Beams Activity
}

\author{
Mila Karmila $^{{ }^{凶}}$, Muhtarom $^{2}$ \\ Pendidikan Guru Pendidikan Anak Usia Dini, Universitas PGRI Semarang \\ DOI: $\underline{10.31004 / o b s e s i . v 6 i 1.1198}$
}

\begin{abstract}
The focus of this research is to explore and describe the ability of children's social behavior through playing beams. This research used qualitative descriptive method, which was used to examine the children's natural activity when playing beams. This research was conducted at the Child Care Center of Child Vocational Education (TPA PENA PRIMA) with the subject as many as 4 early childhood children aged 3-4 years. The data collection method used was observation, documentation and interviews. Data analysis techniques included collecting data, selecting data, presenting data and concluding. The findings of the research showed that there were differences in social behavior in each child in playing beams activities such as imitation, competition, cooperation, sympathy, empathy, social support, sharing, and familiar behavior. This research shows that playing activities and peer roles are essential for optimizing the children's social behavior. Schools are expected to provide supporting facilities for beam playing activities.
\end{abstract}

Keywords: cooperation; empathy; imitate; playing beams; sympathy.

\begin{abstract}
Abstrak
Fokus penelitian ini untuk menggali dan mendeskripsikan kemampuan perilaku sosial anak melalui kegiatan bermain balok. Penelitian ini menggunakan metode deskriptif kualitatif, yang digunakan untuk meneliti aktivitas alamiah anak ketika bermain balok. Penelitian dilakukan di TPA PENA PRIMA dengan subjek sebanyak 4 anak usia dini yang berusia 3-4 tahun. Metode pengumpulan data menggunakan observasi, dokumentasi dan wawancara. Teknik analisis data meliputi pengumpulan data, seleksi data, menyajikan data dan penarikan kesimpualan. Temuan penelitian menunjukan adanya perbedaan perilaku sosial pada masing-masing anak dalam kegiatan bermain balok seperti meniru, persaingan, kerja sama, simpati, empati, dukungan sosial, membagi, dan perilaku akrab. Penelitian ini menunjukkan bahwa aktivitas bermain aktif dan peran teman sebaya sangat penting untuk mengoptimalkan perilaku sosial anak. Sekolah diharapkan menyediakan fasilitas yang mendukung untuk aktivitas bermain balok.
\end{abstract}

Kata Kunci: bekerjasama; empati; meniru; bermain balok; simpati.

Copyright (c) 2021 Mila Karmila, Muhtarom

$\triangle$ Corresponding author :

Email Address : milakarmila@upgris.ac.id (Semarang, Jawa Tengah, Indonesia).

Received 14 March 2021, Accepted 23 March 2021, Published 25 March 2021 


\section{INTRODUCTION}

Early childhood in their development are in the golden age. The social development of early childhood starts from the family environment, residence, and peers. Early childhood attend pre-school activities to develop their social behavior through behavioral interaction with others not only families, but also with peers. Children experience a very rapid growth in adapting to the surrounding environment. Therefore it requires educative and positive stimulation so that children grow and develop into persons who are expected to be smart cognitively, but having affective psychomotor. A very important developmental aspect to be stimulated from the early age is social skill; it is a form of behavior, deeds and attitudes performed by individuals when interacting with others accompanied by accuracy and speed so as to provide comfort for those around them (Suhartini \& Laela, 2018). Early childhood who have good social skills will be figures in the environment, both with peers and with adults around (Machmud, 2019). The research done by Pianta et al. (2008) reveals that children with good social skills will also facilitate children's school readiness.

The patterns of social behavior in children include imitation, competition, cooperation, sympathy, empathy, social support, familiar behavior (Hurlock, 1990). Social behavior in early age childhood includes: a) making contact and playing with other children, b) interacting with peers, giving and receiving, c) associating with peers, to interact harmoniously, d) looking at things from other children's point of view, e) taking turns and waiting for their turns, f) sharing with other children, g) showing respect for the rights of other children, and h) resolving conflicts inter personal (Beaty, 2013). To know that the ability develops in children well, the media used as playing is needed. Junaedah \& Ahmad (2020) describes that changes in social behavior in early children happen when there are friendship, independence, friendliness, and morality. Changes in social development of early childhood in the phase of their life are remarkable. The early childhood become themselves with their own characters, imitating others around them, with their own strengths and weaknesses. At this stage the children do not want to be told to sit too long, and do not like to be prohibited in playing.

Playing with other children provides the best opportunity for children to learn social skill (Dogan et al., 2017; Pianta et al., 2008; Pyle et al., 2018). Playing is a key tool for children's social development as it encourages social interaction (Beaty, 2013). Children learn how to negotiate, resolve conflicts, solve problems, get along, take turns, be patient, cooperate and share. Playing also helps children understand the concept of justice and competition. Playing is a fun-filled activity without coercion, and is more concerned with processes than outcomes (Wood, 2014), self-built initiatives to give pleasure and develop imagination, encourage children to interact socially with their peers, learn to solve problems and role-play for the cognitive development of children. Through playing, social contact and verbal relationships between two or more persons occur (Kelly et al., 2017). Playing is not only beneficial for social development, but is also important for their cognitive growth (Ferliana \& Maria, 2014). Their socialization with friends and the surrounding environment is increasingly visible as children begin to listen, imitate the words, movements, and behaviors of the people around them.

Social behavior has a positive impact on social life, namely the emergence of a sense of harmony, peace, cherishing, and respect (Ismail, 2019). Children who have good social behavior development will easily interact with others so that children can be accepted in the environment (Utami, 2018). However, Solekhah et al. (2018) shows that children aged 5 to 6 years have low social behavior. This can be seen from the fact that children do not want to lend crayons to their friends, do not want to share food with their friends, do not want to study in groups. Through playing beams, children's speaking skills improve (Istiarini, 2014). Beams games can also improve early childhood skills in recognizing number symbols (Pradana, 2016). However, the research above has not elaborated the description of children's social behavior when playing beams. Based on the description above, the formulation of the problem in this research is how to describe children's social behavior through playing activities, especially when playing beams. 


\section{METHODOLOGY}

This research used qualitative method to describe the natural condition of early childhood when playing beams (Miles et al., 2018). This research was conducted at Child Care Center of Child Vocational Education (TPA PENA PRIMA) located at Sidodadi Timur street No. 24 - Dr. Cipto Semarang, Central Java, Indonesia. TPA PENA PRIMA was a Laboratory School of Early Childhood Education Teachers Program, Faculty of Education, Universitas PGRI Semarang. Four children (MR, MZ, AD, and NK) were selected for their social behavior observation because they were in the age range of 2 to 5 years and had been students at PENA PRIMA TPA for at least 1 year. The data source of this research was the observation result at PENA PRIMA TPA conducted for 2 months, when children played beams. When children play with beams, various social behaviors such as cooperation, empathy, imitation, and sympathy are observed by researchers. Researchers took pictures as the documentation during the research took place.

The credibility test was done by extending observations, increasing perseverance, triangulating time, discussing with peers and member checking. Data analysis was done through data reduction steps, data presentation and conclusion. Reducing data meant summarizing, choosing the things that were central and focused. Through data reduction, there was a clear description and it facilitated the researcher in collecting the next data if needed. Data presentation was done in the form of brief description, chart, and relationships between categories of children behavior. Further data were presented in a narrative text. The data were derived from observation, interview, and documentation from March to August, 2019. The last stage in analyzing the data was the concluding the data obtained from the beginning of the research until the end of the research and supported by valid evidence (Miles et al., 2018).

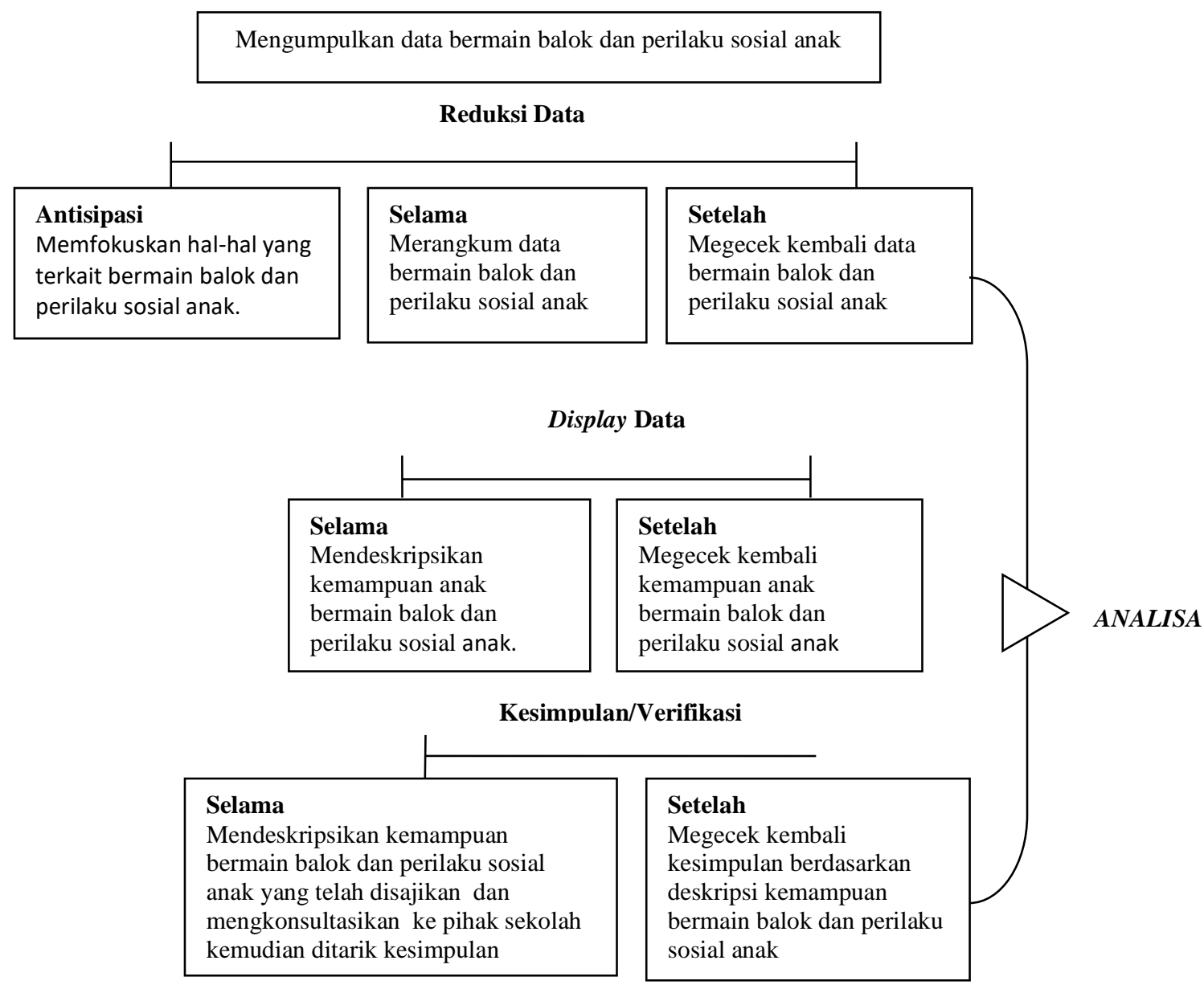

Bagan 3.1 Komponen dalam Analisis Data (flow model) 


\section{RESULTS AND DISCUSSIONS}

The ability of social behavior is important to develop in early childhood, especially positive social behavior. Children can share, cooperate, and do other positive social behaviors. Ability of social behavior in children is the ability of children in viewing their environment, able to interact with their friends, care about their friends, willing to share and realize that its existence is influential and needed by others. For children aged 3-4 years it is done by entering the stimulation into the opening activities as well as sharing the story every morning, playing in the playing centers in the classroom. This can foster social behavior that is done on every activity both inside and outside the classroom. Handling a child who has not been able to behave socially well can be done with various efforts in order to appear positive social behavior such as by telling the characters who want to share, by giving directions slowly so that children feel comfortable, by sharing meals while eating together, by teaching children to love his friends. The research findings related to social behavior in children of TPA PENA PRIMA while playing beams are described as follows:

\section{Participant MR}

Participant MR was not interested in imitating the results of his friend's building. MR preferred building as he liked with his own creativity. For example when other friends built railroads, MR chose to build a zoo. In another activity, MR chose to build beams into a Bank building. It was in contrast to the theme on the day of his friends building beams into a Hospital. Another social behavior that emerged in MR was competition when playing the beams. MR fought over the place to be used for building. MR competed to build with more beams composition, and more details than his friends

MR had shown cooperative behavior in building beams. MR and MZ built the beams into a large zoo. MR built the yard, and the tiger cage, another friend helped him keep the horses, cow and elephant toys into the cage. MR often selected friends who would be invited to work together. The form of cooperation done was MR built while his friend took the beams which would be used. MR also showed social behavior of sympathy. It was seen when MR saw his sister cry and he tried it out to cheer up by giving toys. To get support or attention from his friends, MR often shared food with his friends. When his friend did not support what was done by MR, he would be usually shunned and not given food again, but it only lasted for a moment. Meanwhile, obtaining social support from teachers at TPA PENA Prima was done by disturbing his sister or did not obey the agreement that had been made together. MR could behave intimately only with friends who were often invited to play with him.

\section{Participant AD}

Social behavior shown by participant $\mathrm{AD}$ while playing beams was imitating. AD seemed imitating the building made by his friend but not entirely the same. In the competition when playing beams, $\mathrm{AD}$ was more competitive in fighting over the beams that would be used to build. AD was able to work together in building beams with their friends, but his egocentrism was more dominant, which often led to conflicts with friends, and the conflict did not allow children to clean up the beams when they had finished. The child's sense of sympathy was observed when $\mathrm{AD}$ defended a close friend disturbed by another friend. Likewise, the empathy ability possessed by AD was not much different from the ability of sympathy. It was seen when his friend felt annoyed by other friends because there was no friend to work together in building and then $\mathrm{AD}$ invited him to join him to build beams together. The way to find support done by $\mathrm{AD}$ was by influencing his friend not to follow the agreement that had been made. In sharing ability, AD had been able to do it. It could be seen when distributing his friends' beams. The familiar behavior of AD was only visible with old friends who often met with AD. 


\section{Participant MZ}

Participant MZ social behavior in imitating in building beams with his friends had not been recorded and not as often as other friends. MZ would only imitate the preferred buildings such as building trains, building tunnels and matters relating to trains. Another emerging social behavior was competition. While playing beams, MZ took more beams than his friends to build. Other competition was shown by occupying a wider carpet than his friend. MZ had shown social behavior in cooperation. Like at the time of playing beams, MZ divided the tasks of his friends to get the beams to $A D$, to ask MR to build the road and MZ built the train. Another behavior was seen when MZ helped MR calculate the beams to be picked up at the locker, and with his friend he tidied up the tilted building beams. MZ needed time and arrangement from their teacher to get used to restore the beams that had been used to play together.

Participant MZ showed empathetic behavior in defense when his close friends were harassed by his sister or other friends. MZ's empathy ability was also seen when MZ was saddened when his close friend fell. MZ tried to comfort and encourage MR. The ability to seek social support was done by MZ by whining and shouting when he was reminded to clean up after playing. The ability to share while playing the beam had begun to appear but the nature of egocentrism was still dominant. The familiar behavior that MZ showed was when playing the beams, he wanted to build with only one of his friends.

\section{Participant NK}

Social behavior of NK that was observed included imitating behavior when playing beams together. NK imitated buildings made by his friends, for example NK imitated in making a road. The ability of competition when playing the beam had not been seen because he often gave in. The ability of cooperation had not been visible because he was still cool to play the beams by himself. The empathy of NK was seen when he saw his sister crying, he asked why she was crying. The empathy of NK was seen with the concern of NK with his friend, willing to help the mother who was in distress. In search of social support with his friends had not seen but NK always asked for support or defense of his mother. NK sharing capability was visible when playing beams or outside playing beams. NK familiar behavioral ability had begun to appear when he wanted to play along with his friend.

How to build children's social behavior with peers during playing beams is done with their social contacts of communication between friends where communication is included as part of the process of social interaction that will be shaping social behavior. When children talks to their friends about what building that they build, it is a form of social contact (Kelly et al., 2017; Wood, 2014). Besides, shaping social behavior is also built with the communication that occurs between children during building beams (Ferliana \& Maria, 2014). Relevance of peer interaction with the formation of social behavior confirms research conducted that state parenting factor, social skill, commitment to values, and problems in school contribute to associate with peers and involvement in social behavior (Savolainen et al., 2019; South et al., 2005).

Children in TPA PENA PRIMA showed not only social behavior but also non-social behavior, for example, often seen when children played beams such as power, thinking egoistically, self-centered behavior. The three behaviors referred to the behavior of children's egocentrism. Hurlock (1990) describes non-social behaviors that exist in children such as negativism, aggressive behavior, thinking egoistically, self-centeredness, self-destructiveness, destruction, sex conflict, and prejudice while. Egocentric is a basic process that is often found in children's behavior. Children's observations are largely determined by their own views (Haditono, 2006). Children also do not have orientation on separating the child-object yet.

From observation on children at TPA PENA PRIMA, it was found that children often showed egocentrism in any case, especially when playing beams, children wanted to be able to build using a large number of beams without thinking of friends who want to build as well. 
Children want to build with a wide place whereas the limited place needed to be shared for other friends. Relating to the social behavior ability in children which has been described above is in accordance with the proof of development at their ages (Aghnaita, 2017). Social behavior children are able to imitate, compete, work together with their age, sympathize with their friends, empathize, seek support from their friends and teachers, and behave intimately. However, the ability of social behavior that is owned by each child is different.

When children play with blocks, many social behaviors arise such as cooperation, imitation, empathy and sympathy for other children. The use of beams in early childhood education is intended to develop the ability of children, in addition to providing opportunities for children to explore. Sharpening children's creativity through beams media can develop dimensions of child development such as children's language development, children's motor development as well as children's social development (Kemalawati, 2017). The descriptions of the results of this study are presented qualitatively about descriptions of children's social behavior during playing blocks. Thus, these results can complement quantitative research on the application of block games (Istiarini, 2014; Pradana, 2016).

\section{CONCLUSIONS}

Based on the findings and discussion of the research, it can be concluded that in playing beams, there are social behavioral abilities that develop in children such as, imitating, sympathy, empathy, sharing, and working together. Differences in social behavior are caused by differences in parenting patterns in introducing various aspects of social life, or the norms of social life. Advice to parents in implanting positive social behavior can be done by behaving well, explaining to the child about good behavior and bad behavior. Furthermore, teachers are expected to teach children to behave well in school, provide guidance on behaving well at the time of learning and beyond learning.

\section{ACKNOWLEDGEMENT}

The author would like to thank the financial support from DRPM Ristek-BRIN who has provided funding for this research

\section{REFERENCES}

Aghnaita, A. (2017). Perkembangan fisik-motorik anak 4-5 tahun pada Permendikbud no. 137 Tahun 2014 (Kajian konsep perkembangan Anak). Al-Athfal: Jurnal Pendidikan Anak, 3(2), 219-234. https:// doi.org/10.14421/al-athfal.2017.32-09

Beaty, J. J. (2013). Observing development of the young child (terjemahan Observasi Perkembangan Anak Usia Dini oleh Arif Rakhman). Jakarta: Prenadamedia.

Dogan, R. K., King, M. L., Fischetti, A. T., Lake, C. M., Mathews, T. L., \& Warzak, W. J. (2017). Parent-implemented behavioral skills training of social skills. Journal of Applied Behavior Analysis, 50(4), 805-818. https://doi.org/10.1002/jaba.411

Ferliana, J. M., \& Maria, A. (2014). Meningkatkan Kemampuan berkomunikasi aktif pada anak usia dini. Jakarta: Luxima Metro Media.

Haditono, S. R. (2006). Psikologi perkembangan: Pengantar dalam berbagai bagiannya. Yogyakarta: Gajah Mada University Press.

Hurlock, E. B. (1990). Psikologi perkembangan edisi 5. Jakarta: Erlangga.

Ismail, I. H. (2019). Pola asuh orang tua yang otoriter dalam keluarga (Dampak perkembangan perilaku anak di Desa Kaloling Kecamatan Sinjai Timur Kabupaten Sinjai). Jurnal Mimbar: Media Intelektual Muslim dan Bimbingan Rohani, 5(2), 43-64. https:// doi.org/10.47435/mimbar.v1i1.267

Istiarini, R. (2014). Peningkatan kemampuan berbicara melalui bermain balok. Jurnal Pendidikan Usia Dini, 8(1), 145-154. 
Junaedah, S. B. T., \& Ahmad, M. A. (2020). The outdoor learning modules based on traditional games in improving prosocial behaviour of early childhood. International Education Studies, 13(10). https:// doi.org/10.5539/ies.v13n10p88

Kelly, M. E., Duff, H., Kelly, S., Power, J. E. M., Brennan, S., Lawlor, B. A., \& Loughrey, D. G. (2017). The impact of social activities, social networks, social support and social relationships on the cognitive functioning of healthy older adults: A systematic review. Systematic Reviews, 6(1), 1-18. https:// doi.org/10.1186/s13643-017-0632-2

Kemalawati, I. (2017). Upaya meningkatkan kreativitas anak melalui alat permainan balok di Taman Kanak-Kanak Cipta Mulia Kecamatan Cipatat Kabupaten Bandung Barat. EMPOWERMENT: Jurnal Ilmiah Program Studi Pendidikan Luar Sekolah, 6(1).

Machmud, H. (2019). Pengaruh pola asuh terhadap keterampilan sosial anak (Penelitian expost facto pada paud rintisan di Kendari). Al-TA'DIB: Jurnal Kajian Ilmu Kependidikan, 127-145.

Miles, M. B., Huberman, A. M., \& Saldaña, J. (2018). Qualitative data analysis: A methods sourcebook. Sage publications.

Pianta, R. C., Mashburn, A. J., Downer, J. T., Hamre, B. K., \& Justice, L. (2008). Effects of webmediated professional development resources on teacher-child interactions in prekindergarten classrooms. Early Childhood Research Quarterly, 23(4), 431-451. https://doi.org/10.1016/j.ecresq.2008.02.001

Pradana, P. H. (2016). Pengaruh permainan balok angka terhadap kemampuan mengenal lambang bilangan pada Anak Usia Dini. Jurnal Obsesi: Jurnal Pendidikan Anak Usia Dini, 2(2), 117-124.

Pyle, A., Prioletta, J., \& Poliszczuk, D. (2018). The play-literacy interface in full-day kindergarten classrooms. Early Childhood Education Journal, 46(1), 117-127. https:// doi.org/10.1007/s10643-017-0852-z

Savolainen, I., Sirola, A., Kaakinen, M., \& Oksanen, A. (2019). Peer group identification as determinant of youth behavior and the role of perceived social support in problem gambling. Journal of Gambling Studies, 35(1), 15-30. https://doi.org/10.1007/s10899018-9813-8

Solekhah, A. M., Atikah, T. P., \& Istiqomah, M. (2018). Faktor-faktor yang mempengaruhi sikap empati terhadap perilaku prososial pada anak Sekolah Dasar. Prosiding Seminar Nasional "Penguatan Pendidikan Karakter Pada Siswa Dalam Menghadapi Tantangan Global". Prosiding Seminar Nasional Kudus: Universitas Muria Kudus.

South, M., Ozonoff, S., \& McMahon, W. M. (2005). Repetitive behavior profiles in Asperger syndrome and high-functioning autism. Journal of Autism and Developmental Disorders, 35(2), 145-158. https:// doi.org/10.1007/s10803-004-1992-8

Suhartini, Y., \& Laela, A. (2018). Meningkatkan kecerdasan natural Anak Usia Dini melalui pengenalan hewan di TK Pelita Kota Bandung. Jurnal Obsesi: Jurnal Pendidikan Anak Usia Dini, 2(1), 45-53. https:// doi.org/10.31004/obsesi.v2i1.6

Utami, D. T. (2018). Pengaruh lingkungan teman sebaya terhadap perilaku sosial Anak Usia 5-6 tahun. Generasi Emas: Jurnal Pendidikan Islam Anak Usia Dini, 1(1), 39-50. https://doi.org/10.25299/ge.2018.vol1(1).2258

Wood, E. A. (2014). Free choice and free play in early childhood education: Troubling the discourse. International Journal of Early Years Education, 22(1), 4-18. https://doi.org/10.1080/09669760.2013.830562 